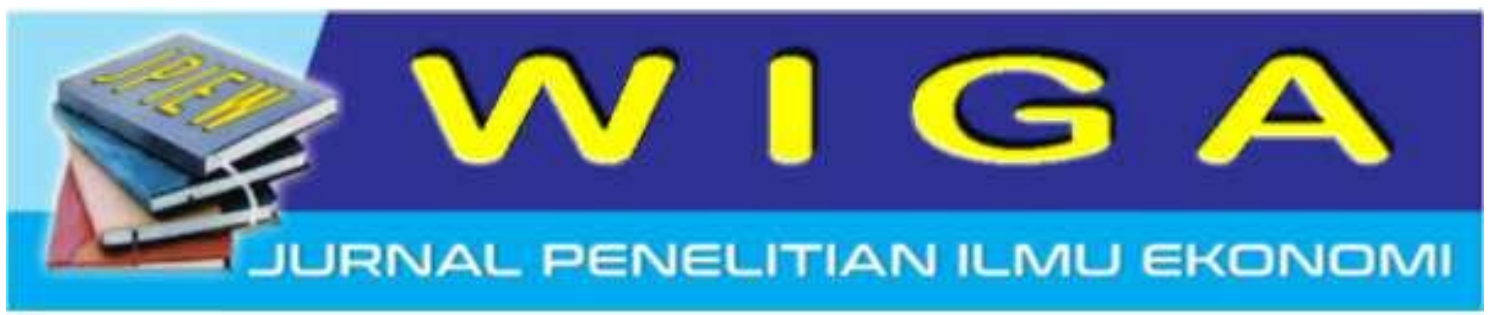

\title{
Analisis Kinerja Perangkat Desa di Kabupaten Lumajang
}

\author{
Moh. Hudi Setyobakti ${ }^{1}$ \\ STIE Widya Gama Lumajang \\ email : hudisetyobakti@gmail.com \\ Wahyuning Murniati ${ }^{2}$ \\ STIE Widya Gama Lumajang \\ email: wahyuning123@gmail.com
}

\begin{abstract}
Abstrak
Perangkat desa merupakan salah satu faktor penting dalam berjalannya proses pemerintahan di desa. Oleh karena itu diperlukan suatu analisis untuk mengetahui faktor-faktor yang mempengarugi kinerja dari perangkat desa. Terdapat dua variable bebas dalam penelitian ini, yaitu; etos kerja dan disiplin kerja. Dalam prosesnya penelitian ini menggunakan perangkat desa di Kabupaten Lumajang sebagai populasi dengan 64 responden. Selanjutnya untuk teknik analisis data menggunakan analisis regresi linier berganda dimana hasil analisisnya menunjukkan bahwa baik etos kerja maupun motivasi berpengaruh signifikan terhadap kinerja perangkat desa. Hal ini didukung dengan nilai koefisien determinasi sebesar 73,4\% sehingga hanya bersisa $26,6 \%$ untuk variabel lain yang mempengaruhi kinerja perangkat desa. Penelitian ini diharapkan dapat memberikan kontribusi dalam pengembangan kajian ilmu manajemen khususnya manajemen sumber daya manusia sehingga dapat menjadi acuhan penelitian selanjutnya.
\end{abstract}

\section{Kata kunci: Kinerja, Etos Kerja, Disiplin}

\begin{abstract}
Village apparatus is an important factor in the running of the government process in the village. Therefore an analysis is needed to determine the factors that affect the performance of the village apparatus. There are two independent variables in this study, namely; work ethic and work discipline. In the process this study uses village tools in Lumajang District as a population with 64 respondents. Furthermore, for data analysis techniques using multiple linear regression analysis, the results of the analysis show that both work ethic and motivation have a significant effect on the performance of the village apparatus. This is supported by the coefficient of determination of $73.4 \%$ so that only $26.6 \%$ remains for other variables that affect the performance of village equipment. This research is expected to contribute to the development of studies in management science, especially human resource management so that it can become a reference to further research.
\end{abstract}




\section{PENDAHULUAN}

Lahirnya Undang Undang Nomor 6 tahun 2014 tentang Desa yang selanjutnya disingkat UU Desa, memberikan kedudukan penting bagi desa untuk dapat menjalankan perannya dalam pembangunan nasional. Wujud peran penting desa adalah adanya kewenangan lokal yang dimiliki oleh desa dalam mengatur rumah tangganya. Peran strategis ini yang kemudian diterjemahkan dalam wujud implementasi pembangunan desa mulai dari proses perencanaan, pelaksanaan dan pertanggungjawaban kegiatan.

Desa sebagai satu kesatuan masyarakat hukum yang memiliki batas wilayah yang berwenang untuk mengatur dan mengurus urusan pemerintahan, kepentingan masyarakat setempat berdasarkan prakarsa masyarakat, hak asal usul. Didalam menjalankan urusan tersebut, maka peran pemerintah desa sangat penting. Pemerintah Desa yang dalam hal ini dipimpin oleh Kepala Desa dan dibantu perangkat desa mempunyai peran dalam penyelenggaraan pemerintahan desa. Pemerintah desa diharapkan dapat memberikan pelayanan yang baik bagi masyarakat. Kinerja maksimal dari para perangkat desa inilah yang diharapkan dapat terwujud, sehingga tujuan penyelenggaraan pemerintahan dapat tercapai.

Kualitas kinerja merupakan ukuran dalam menentukan pencapaian tujuan suatu organisasi. Keberhasilan sebuah organisasi dalam meningkatkan kinerja sangat tergantung pada sumber daya manusia yang terlibat didalamnya. Terdapat beberapa faktor yang tentunya mempengaruhi terhadap kualitas kinerja para perangkat desa, khususnya di kabupaten Lumajang, sehingga hal inilah yang menarik perhatian peneliti, untuk meneliti faktor apa saja yang mempengaruhi terhadap kinerja perangkat desa di Kabupaten Lumajang, sehingga diharapkan menjadi kontribusi positif bagi pemerintah desa dalam memberikan pelayanan yang lebih baik kepada masyarakat. Adapun faktor faktor yang menjadi variabel yang akan diteliti adalah menyangkut tentang etos kerja dan disiplin kerja perangkat desa. Berdasarkan uraian di atas, maka peneliti akan melakukan penelitian yang berjudul "Faktor Faktor Yang Mempengaruhi Kinerja Perangkat Desa Pada Pemerintah Desa Di Kabupaten Lumajang"

\section{KAJIAN PUSTAKA Etos Kerja}

K. Bertens (2008:282) menyatakan "bahwa secara etimologis istilah etos berasal dari bahasa yunani yang berarti "tempat hidup". Mula mula tempat hidup di maknai sebagai adat istiadat atau kebiasaan.sejalan dengan waktu,kata etos berevolusi dan berubah makna menjadi semakin kompleks. Dari kata yang sama muncul pula istilah "ethikos" yang di pahami sebagai "teori kehidupan", yang kemudian menjadi "etika". Etos dalam bahasa indonesia sering di sebut dengan sifat dasar,pemunculan atau disposisi (watak)".

Webster Dictionary mendefinisikan etos kerja "Guiding beliefs of a person, group or institution".Etos adalah keyakinan yang menentukan seseorang, kelompok atau suatu institusi. Sedangkan dalam The American Heritage Dictionary of English language (Anora,2009) menyatakan bahwa etos dapat di pahami dari dua makna yaitu :

a. The dispotion, character, or attitude peculiar to a specific people, cutture or a group that distibguises it from other peoples or group, fundamental values or spirit, mores. Disposisi, karakter atau sikap kusus orang, budaya atau kelompok lain, nilai atau jiwa yang mendasari, adat-istiadat,

b. The guverbing or central principles in a movement, work of art, mode of expression, or the like. Prinsip utama atau pengendali dalam suatu pergerakan, pekerjaan seni, bentuk expresi, atau sejenisya. 
Anaroga (2009) menyatakan bahwa "etos kerja merupakan suatu pandangan dan sikap suatu bangsa atau umat terhadap kerja. Bila individu-individu dalam komunitas memandang kerja sebagai suatu hal yang luhur bagi ektisensi manusia, maka etos kerjanya akan cenderung tinggi. sebaliknya sikap dan pandangan terhadap kerja sebagai sesuatu yang bernilai tinggi bagi kehidupan, maka etos kerja dengan sendirinya akan rendah".

Sinamo (2005) juga memandang bahwa etos kerja merupakan fondasi dari sukses yang sejati dan otentik.pandangan ini di pengaruhi oleh kajiannya terhadap studi-studi sosiologi sejak jaman Max Weber di awal abad ke-20 dan penulisanpenulisan manajemen dua puluh tahun belakangan ini yang semuanya bermuara pada kesimpulan utama bahwa keberhasilan di berbagai wilayah kehidupan di tentukan oleh prilaku manusia, terutama perilaku kerja. Kesimpulan penulis bahwa etos kerja merupakan seperangkt sikap atau pandangan mendasar yang di pegang pegawai untuk menilai bekerja sebagai suatu hal yang positif bagi peningkatan kualitas kehidupan,sehingga mempengaruhi prilaku kerjanya dalam organisasi, Doni juni priansa (2014:282)

Berdasarkan pengertian tersebut, maka etos merupakan seperangkat pemahaman dan keyakinan terhadap nilai-nilai yang secara mendasar mempengaruhi kehidupan, menjadi prinsip-prinsip pergerakan, dan cara berekspresi yang khas pada sekelompok orang dengan budaya serta keyakinan yang sama.

\section{Kedisiplinan}

"Disiplin kerja adalah suatu alat yang digunakan para manajer untuk berkomunikasi dengan karyawan agar mereka bersedia untuk mengubah suatu perilaku serta sebagai suatu upaya untuk meningkatkan kesadaran dan kesediaan seseorang mentaati semua peraturan perusahaan dan norma-norma sosial yang berlaku".

"Kedisiplinan merupakan fungsi operatif manajemen sumber daya manusia yang terpenting karena semakin baik disiplin karyawan, semakin tinggi prestasi kerja yang dapat dicapainya" (Malayu S,P. Hasibuan 2008:193).

Berdasarkan pengertian tersebut maka disiplin kerja merupakan perilaku individu dalam sebuah organisasi yang mengacu pada standar yang ditetapkan oleh organisasi yang harus dipatuhi dan dilaksanakan oleh setiap individu yang ada dalam organisasi tersebut

\section{Kinerja}

"Manajemen kinerja itu berasal dari kata performance yang berarti hasil pekerjaan atau prestasi kerja. Namun perlu pula di pahami bahwa kinerja itu bukan sekedar hail pekerjaan atau prestasi kerja tetapi juga mencakup bagaimana proses pekerjaan itu berlangsung" (Wibowo, 2007:7).

Terdapat beberapa pandangan para pakar tentang pengertian kinerja, diantaranya: "Kinerja merupakan hasil pekerjaan yang mempunyai hubungan kuat dengan tujuan strategis orgnisasi, kepuasan konsumen, dan memberikan kontribusi pada ekonomi" (Armstrong dan Baron,1998 dalam Wibowo, 2007:7).

"Manajemen kinerja sebagai proses komunikasi yang dilakukan secara terusmenerus dalam kemitraan antara karyawan dengan atasan langsungnya" (Bacal, 1999:4).

Berdasarkan pengertian di atas maka kinerja sebagai sarana untuk mendapatkan hasil yang lebih baik dari organisasi, tim, dan individu dengan cara memahami dan mengelola kinerja dalam suatu kerangka tujuan, standar, dan persyaratanpersyaratan atribut yang disepakati.

\section{Penelitan Terdahulu}

Terdapat beberapa penelitian terdahulu yang digunakan sebagai acuan dalam penelitian ini, antara lain;

a. Safitri indriani (2015) Melakukan penelitian dengan judul "Pengaruh Pelatihan Kerja Dan Disiplin Kerja Terhadap Produktifitas Kerja Karyawan Pada PT. Padise Island Furniture". Terdapat pengaruh positif 
dan signifikan pelatihan kerja dan disiplin kerja terhadap produktivitas kerja karyawan pada PT. Paradise Island Furniture.

b. Adeyeye, J.O (2015), melakukan penelitian dengan judul "Effects of Workplace Ethics on Employees and Organisational Productivity in Nigeria". Hasil menunjukkan bahwa terdapat hubungan yang signifikan antara etika standar dan produktivitas organisasi, di Nigeria dan bahwa disiplin integritas cum memiliki dampak negatif pada peningkatan tingkat produktivitas organisasi, yang dapat dikaitkan dengan sifat kebajikan menjadi abstrak dan hanya dapat dilihat atau diamati lembur.

c. Anwar Prabu Mangkunegara (2015), melakukan penelitian dengan judul "Effect of Work Discipline, Work Motivation and Job Satisfaction on Employee Organizational Commitment in the Company (Case Study in PT. Dada Indonesia)"..Hasil penelitian ini menunjukkan kepada mereka bahwa Disiplin Kerja berpengaruh positif terhadap Komitmen Organisasi.Motivasi kerja berpengaruh positif terhadap Komitmen Organisasi.

d. Wawan Ridwan Mutaqin (2010), melakukan penelitian dengan judul "Pengaruh Iklim Organisasi, Etos Kerja dan Disiplin Kerja Terhadap Efektifitas Kinerja Organisasi di Politeknik Kesehatan Surakarta". Penelitian ini menunjukkan bahwa efektifitas kinerja organisasi dipengaruhioleh iklim organisasi, etos kerja dan disiplin kerja.

e. Fenny Dwi Oktavia (2014), melakukan penelitian dengan judul "Pengaruh Kepemimpinan dan Disiplin Kerja Terhadap Kinerja Pegawai Pada Dinas Pendidikan Kota Bengkulu". Berdasarkan hasil penelitian dapat disimpulkan bahwa kepemimpinan memiliki pengaruh yang positif terhadap kinerja pegawai, disiplin Kerja memiliki pengaruh yang positif terhadap kinerja pegawai. f. Anisa Novita sari (2008) Melakukan penelitian dengan judul "Hubungan Motivasi Kerja Dan Dsiplin Kerja Dengan Produktifitas Kerja Pegawai Dinas Pekerjaan Umum Kabupaten Grobokan". Adanya hubungan yang signifikan antara motivasi dan disiplin terhadap produktivitas kerja, sehingga dapat disimpulkan bahwa hipotesis dapat diterima secara signifikan.

g. Ilham thaif (2015) melakukan penelitian denmgan juul "Effect of Training, Compensation and Work Discipline against Employee Job Performance (Studies in the Office of PT. PLN (Persero) Service Area and Network Malang)". Hasil penelitian tersebut menunjukan Pelatihan, kompensasi dan disiplin kerja secara simultan dan parsial memilikiefek yang signifikan terhadap kinerja kerja karyawan di PT. PLN (Persero) Jasa Malang dan JaringanDaerah.Seluruh efek dari variabel independen memiliki arah yang positif. Kontribusi terbesar dating dari variabel pelatihan.

h. Stela Timbulang (2015) melakukan penelitian denga judul "Etos Kerja, Disiplin Kerja, Dan Komitmen Organisasi Pengaruhnya Terhadap Kinerja Karyawan Pada PT Hasjrat Abadi Cabang MANADO. Hasil penelitian menunjukan bahwa secara simultan etos kerja,disiplin kerja dan komitmen organisasi berpengaruh positif dan signifikan terhadap kinerja karyawan sedangkan secara parsial etos kerja tidak berpengaruh terhadap kinerja karyawan sebaliknya disiplin kerja dan komitmen organisasi berpengaruh terhadap kinerja karyawan.

i. Simon Yuarto (2014) Melakukan penelitian dengan judul "Pengaruh Disiplin Dan Setres Kerja Terhadap Kinerja Perawat" hasil penelitian menunjukan analisis regresi dan menyimpulkan bahwa disiplin stres dan bekerja secara simultan untuk mempengaruhi kinerja perawat.Sementara itu, tidak stres variabel secara parsial berpengaruh 
pada kinerja perawat dan disiplin efek parsial pada kinerja perawat.

j. Resti Lufitasari (2014) Melakukan penelitian dengan judul "Pengaruh Motivasi Kerja, Disiplin Kerja Dan Kompensasi Terhadap Kinerja Karyawan Pada Dinas Pendapatan, Pengelolaan Keuangan Dan Aset D.I. Yogyakarta" hasil penelitian menunjukan Terdapat pengaruh positif namun tidak signifikan Motivasi Kerja terhadap Kinerja Karyawan.

k. Roni dwi prasetyo (2016) Melakukan penelitian dengan judul "Pengaruh Kedisiplinan dan Motivasi kerja terhadap Kinerja Pegawai kantor Badan Narkotika Nasional Kabupaten Lumajang" hasil penelitian menunjukan Terdapat pengaruh positif namun tidak signifikan Motivasi Kerja dan disiplin kerja terhadap Kinerja Pegawai.

\section{METODE PENELITIAN}

Penelitian ini termasuk jenis penelitian kuantitatif dengan pendekatan survei (survei research) yaitu penelitian yang tidak melakukan perubahan atau tidak ada perlakuan khusus terhadap variabelvariabel yang diteliti (non experimental). Tujuan penelitian ini bersifat eksplanatori (explanatory research) dimana penelitian eksplanatori merupakan jenis penelitian yang menjelaskan hubungan kausal antara satu variabel dengan variabel lainnya melalui pengujian hipotesis.

Penelitian ini dilakukan terhadap pemerintah desa yang ada di Kabupaten Lumajang sejumlah 198 desa. Pengambilan sampel dilakukan denga metode purposive sampling dengan kriteria sebagai berikut;

a. Pemerintah desa yang ada di kabupaten Lumajang

b. Keterwakilan 4 (empat) wilayah yang mencerminkan karakteristik desa yang berbeda yaitu wilayah Utara, Selatan, Barat dan Timur.

c. Setiap keterwakilan wilayah akan diambil sampel 3 (tiga) Desa.

d. Setiap desa diambil responden sebanyak 5 (lima) responden.
Dari seluruh kuesioner yang disebari pada populasi, didapat 64 responen yang digunakan sebagai sampel dalam penelitian ini.

\section{Teknik Analisis Data}

Pada tahap awal dilakukan pengujian instrumen penelitian karena berupa kuesioner, yaitu pengujian validitas dan reliabilitas. Selanjutnya dilakukan analisis regresi linier berganda dengan uji asumsi klasik yang meliputi pengujian normalitas data, multikolinearitas dan heteroskedastisitas. Tahap selanjutnya dilakukan pengujian hipotesis secara parsial dan simultan untuk setiap variabel yang digunakan dalam penelitian ini.

\section{HASIL DAN PEMBAHASAN Hasil Penelitian}

Pengujian instrumen penelitian memberikan hasil bahwa kuesioner valid dan reliabel menjaring pendapat responden dalam penelitian sedangkan untuk pengujian asumsi klasik didapat hasil bahwa data berdistribusi normal, bebas multikolineritas dan bebas heteroskedatisitas. Sedangkan untuk model persamaan regresi yang dapat ditulis dari hasil tersebut dalam bentuk persamaan regresi Unstandardized coefficients adalah sebagai berikut :

$$
Y=5,994+0,517 X_{1}+0,346 X_{2}
$$

Dimana;

$Y_{1} \quad$ : Variabel kinerja

$X_{1}: \quad$ Variabel etos kerja

$X_{2}$ : Variabel disiplin kerja

\section{Pembahasan}

\section{a. Pembahasan Hipotesis Pertama}

Hipotesis pertama menyatakan bahwa etos kerja perangkat desa berpengaruh signifikan terhadap kinerja perangkat desa di Kabupaten Lumajang. Hasil penelitian menunjukkan bahwa etos kerja memang berpengaruh signifikan terhadap kinerja pada perangkat desa di Kabupaten Lumajang. Hal ini terlihat pada hasil pengujian hipotesis secara parsial atau individu dimana nilai Sig. sebesar 0,000 < $\alpha(5 \%)$. 
Berdasarkan uraian item yang dinyatakan dalam kuesioner yang terdiri dari pernyataan (1) Saya bekerja sungguhsungguh dalam melaksanakan pekerjaan saya, (2) Saya memanfaatkan waktu kerja untuk melaksanakan pekerjaan di lembaga ini, (3) Saya merasa puas jika dapat menyelesaikan pekerjaan sesuai dengan waktu yang diberikan, (4) Saya selalu bekerja sesuai dengan peraturan yang telah ada di lembaga ini, (5) Saya bekerja dengan penuh tanggung jawan sehingga pekerjaan selesai dengan optimal, (6) Saya selalu menjaga kesopansantunan selama berada di lembaga ini, (7) Saya tidak merasa terbebani dengan semua pekerjaan yang saya lakukan di lembaga ini, (8) Saya mempunyai kepedulian yang tinggi terhadap tujuan pemerintah desa, (9) Saya selalu berusaha meningkatkan efisiensi dan produktifitas kerja, dan (10) Saya selalu berusaha meningkatkan kemampuan diri saya yang berkaitan dengan pekerjaan, diketahui bahwa mayoritas responden menyatakan persetujuannya pada setiap pernyataan. Hasil pada penelitian ini berbanding terbalik dengan peneletian sebelumnya yang dilakukan oleh Stela Timbulang (2015), dimana secara parsial etos kerja tidak berpengaruh terhadap kinerja karyawan pada PT Hasjrat Abadi di Cabang Manado.

Bisa disimpulkan bahwa perangkat desa di Kabupaten Lumajang memiliki etos kerja yang baik dalam setiap pekerjaan yang dilakukan. Setiap individu berusaha untuk bekerja maksimal dan meningkatkan kualitas pekerjaan yang dilakukan dengan tidak mempedulikan segala hal yang dapat menghambat penyelesaian pekerjaan mereka. Mereka sepakat menginginkan tujuan yang sama yaitu bagaimana mereka bisa memberikan manfaat untuk melayani masyarakat di daerah perdesaan. Namun demikian berdasarkan hasil penelitian ini tetap disarankan untuk memperhatikan kesejahteraan dan kenyamanan petugas dalam menjalankan tugasnya sebagai pengelola kegiatan, karena bagaimanapun mereka adalah manusia yang pada akhirnya juga terbentur kepada kebutuhan pokok yang harus dipenuhi dan membutuhkan motivasi yang besar untuk bisa tetap bertahan pada tugasnya. Jika kebutuhan pokok mereka tidak terpenuhi maka dikhawatirkan akan terjadi penyimpangan dalam pekerjaan atau pengelolaan dananya mengingat dana yang dikelola dalam program nasional ini bukan dana dalam jumlah yang sedikit. Jadi kesejahteraan mereka tetap harus diperhatikan.

\section{b. Pembahasan Hipotesis Kedua}

Hipotesis kedua menyatakan bahwa disiplin kerja perangkat desa berpengaruh signifikan terhadap kinerja perangkat desa di Kabupaten Lumajang. Hasil penelitian menunjukkan bahwa disiplin kerja memang berpengaruh signifikan terhadap kinerja pada perangkat desa di Kabupaten Lumajang. Hal ini terlihat pada hasil pengujian hipotesis secara parsial atau individu dimana nilai Sig. sebesar 0,000 < $\alpha(5 \%)$.

Berdasarkan uraian item yang dinyatakan dalam kuesiner untuk variabel ini yang terdiri dari pernyataan sebagai berikut; (1) Saya berusaha melaksanakan semua peraturan yang berlaku selama bekerja, (2) Saya datang dan pulang tepat waktu sesuai dengan peraturan yang berlaku, (3) Saya memakai seragam selama jam kerja sesuai dengan peraturan yang berlaku, (4) Saya dapat menyelesaikan pekerjaan yang ditugaskan tepat waktu, (5) Saya membagi waktu kerja secara optimal dalam pekerjaan sehingga dapat selesai dengan maksimal, (6) Saya selalu mengikuti setiap pelatihan yang diselenggarakan pemerintah untuk peningkatan kualitas kerja, (7) Saya selalu berusaha untuk masuk kerja sesuai dengan aturan yang berlaku, (8) Dalam setiap pelaksanaan kerja, saya selalu memperhatikan prosedur kerja yang telah ditetapkan sebelumnya, (9) Saya memberi tahu terlebih dahulu (surat ijin) jika absen kerja, dan (10) Saya tidak pernah meninggalkan tempat kerja selama jam kerja berlangsung, diketahui bahwa tingkat persetujuan responden cukup tinggi yang diketahui dari mayoritas menjawab setuju untuk setiap item pernyataan dalam 
kuesioner terkait disiplin kerja. Hasil penelitian ini berbanding lurus dengan semua penelitian sebelumnya yang digunakan, dimana disiplin kerja memberikan pengaruh positif pada kinerja karyawan.

Kesimpulan yang dapat diambil adalah bahwa perangkat desa di Kabupaten Lumajang memiliki disiplin kerja yang tinggi. Setiap individu berusaha mematuhi semua peraturan yang berlaku dengan semua konsekuensi yang ada. Dengan tingkat kedisiplinan yang tinggi maka pekerjaan yang dihasilkan akan maksimal dan dapat diselesaikan tepat waktu sesuai dengan tenggat waktu yang diberikan oleh pimpinan pemerintaan desa. Namun tentu saja terdapat hal lain yang mempengaruhi tingkat kedisiplinan perangkat desa, misalkan saja fasilitas dalam penyelesaian pekerjaan, perhatian pimpinan dan lain sebagainya. Hal ini harus tetap diperhatikan agar tercapai taraf disiplin yang sesuai sehingga akan meningkatkan kualitas kerja setiap pegawai

\section{c. Pembahasan Hipotesis Ketiga}

Hipotesis ketiga menyatakan bahwa etos kerja dan disiplin kerja perangkat desa berpengaruh secara simultan terhadap kinerja perangkat desa. Subbab ini memberikan pembahasan keduanya secara simultan atau bersama-sama dalam mempengaruhi variabel terikatnya, yaitu kinerja perangkat desa di Kabupaten Lumajang. Hasil penelitian ini menunjukkan bahwa kedua variabel ini mempengaruhi kinerja perangkat desa secara simultan, yang artinya hipotesis ketiga ini diterima atau terbukti benar. Hal ini ditunjukkan pada nilai Sig. pada uji F dimana nilainya sebesar $0,000<\alpha(5 \%)$.

\section{d. Koefisien Determinasi $\left(\mathbf{R}^{\mathbf{2}}\right)$}

Koefisien determinasi ( $R$ Square) yang diperoleh sebesar 0,734. Hal ini berarti $73,4 \%$ kinerja petugas unit pengelola kegiatan dapat dijelaskan oleh variabel etos dan disiplin kerja, sedangkan sisanya yaitu 26,6\% kinerja dipengaruhi oleh variabelvariabel lainnya yang tidak diteliti dalam penelitian ini

\section{KESIMPULAN DAN SARAN Kesimpulan}

Berdasarkan hasil penelitian dan pembahasan yang telah diuraikan di atas, maka dapat diambil beberapa kesimpulan sebagai berikut :

a. Etos kerja berpengaruh secara parsial pada kinerja perangkat desa di Kabupaten Lumajang

b. Disiplin kerja berpengaruh secara parsial pada kinerja perangkat desa di Kabupaten Lumajang

c. Etos dan Disiplin kerja mempunyai pengaruh yang signifikan secara simultan terhadap kinerja perangkat desa di Kabupaten Lumajang

\section{Saran}

Atas hasil penelitian dan pembahasan di atas, maka diberikan saran-saran kepada beberapa pihak sebagai berikut :

a. Bagi Pihak Pemerintahan Desa di Kabupaten Lumajang.

Pimpinan Pemerintahan Desa di Kabupaten Lumajang, agar tetap memperhatikan kebutuhan perangkat desa terkait dengan pelaksanaan tugas serta memperhatikan kesejahterahan perangkat desa. Hal ini sepenuhnya untuk menghindari penurunan kualitas etos kerja dan disiplin kerja perangkat desa.

b. Bagi Perangkat Desa di Kabupaten Lumajang

Setiap tugas yang dilakukan dalam pemerintahan desa memiliki tugas yang berkaitan dengan pelayanan kepada masyarakat. Oleh karena itu disarankan kepada setiap perangkat desa untuk selalu meningkatkan kemampuan diri dan selalu menjaga motivasi diri untuk memberikan pelayanan yang terbaik kepada masyarakat. Menyesuiakan dan membuat lingkungan kerja menjadi nyaman dna menyenangkan akan membuat hal ini menjadi salah satu sumber kepuasan kerja yang dapat meningkatkan kinerja.

c. Bagi Penelitian Selanjutnya 
Keterbatasan penelitian ini adalah hanya meneliti pada etos kerja dan disiplin kerja perangkat desa, oleh karena itu bagi peneliti selanjutnya disarankan untuk melakukan penelitian yang meneliti variabel lain yang dapat mempengaruhi kinerja. Mengingat responden yang diteliti berbeda karakternya dengan sumber daya manusia maka akan sangat menarik jika sering dilakukan penelitian dengan obyek program pemberdayaan masyarakat.

\section{DAFTAR PUSTAKA}

Atmaja, Lukas Setia. 2009. Statistika untuk Bisnis dan Ekonomi. Yogyakarta: Penerbit Andi.

Abdullah, Ma'ruf.2014. Manajemen dan Evaluasi Kinerja Karyawan.Yogyakarta: Aswaja Pressindo.

Fahmi, Irham. 2013. Manajemen Kinerja Teori Dan Aplikasi . Penerbit ALFABETA, CV . No. 84 Bandung

Handoko, T. Hani.2001. Manajemen Sumber Daya Manusia. Jakarta: Bumi Aksara. . 2008. Manajemen Personalia dan Sumberdaya Manusia. Edisi Kedua. BPFE-Yogyakarta. Yogyakarta.

Hasibuan, Malayu S.P..2008. Manajemen Sumber Daya Manusia.Jakarta: PT Bumi Aksara.

Indriani, Safitri. 2015. Pengaruh Pelatihan Kerja Dan Disiplin Kerja Terhadap Produktifitas Kerja Karyawan Pada PT. Padise Island Furniture. (online). (http//ejournal:undip.ac.id). diakses 19 Maret 2017.

J.O, Adeyeye. 2015. Effects of Workplace Ethics on Employees and Organisational Productivity in Nigeria. (online). (http//worldofjournal.com). diakses 15 Maret 2017.

Kuncoro, Mudrajad. 2007. Metode Kuantitatif. Unit Penerbit dan
Percetakan. (UPP) STIM YKPN. Yogyakarta.

Lufitasari , Resti.2014. Pengaruh Motivasi Kerja, Disiplin Kerja dan Kompensasi Terhadap Kinerja Karyawan Pada Dinas Pendapatan, Pengelolaan Keuangan Dan Aset D.I. Yogyakarta. (online). (http//ejournal:undip.ac.id). diakses 10 Februari 2017.

Mangkunegara, Anwar Prabu. 2015. Effect of Work Discipline, Work Motivation and Job Satisfaction on Employee Organizational Commitment in the Company (Case Study in PT. Dada Indonesia). (online). (http//e-journal:unpnveteransby.ac.id). diakses 10 Maret 2017.

Mutaqin, Wawan Ridwan. 2010. Pengaruh Iklim Organisasi, Etos Kerja dan Disiplin Kerja Terhadap Efektifitas Kinerja Organisasi di Politeknik Kesehatan Surakarta. (online). (http//e-journal:unsm.ac.id). diakses 10 Maret 2017.

Nugroho, Yohanes Anton. 2011. It's Easy Olah Data Dengan SPSS. Yogyakarta: Skripta Media Creative.

Oktavia, Fenny Dwi. 2014. Pengaruh Kepemimpinan dan Disiplin Kerja Terhadap Kinerja Pegawai Pada Dinas Pendidikan Kota Bengkulu. (online). (http//e-journal:uny.ac.id). diakses 14 Februari 2017.

Priansa, Donni Juni. 2014. Perencanaan \& Pengembangan Sumber Daya Manusia.

Suwatno dan Donni Juni Priansa.2011. Manajemen SDM dalam Organisasi Publik dan Bisnis.Bandung: Alfabeta.

Rivai, Veithzal. Dan Ella Jauvani Sagala.2011. Manajemen Sumber Daya Manusia untuk Perusahaan.Dari Teori ke Praktik.Jakarta: PT Raja Grafindo Persada.

2012. Kepemimpinan dan Perilaku Organisasi. Edisi Ketiga. PT Raja Grafindo Persada. Jakarta. 
Santoso, Singgih. 2012. Metodelogi Penelitian. Bandung. CV. Alfabeta.

Sutrisno, Edy.2009. Manajemen Sumber Daya Manusia.Jakarta: Prenada Media Grup.

Sari, Anisa Novita. 2008. Hubungan Motivasi Kerja Dan Dsiplin Kerja Dengan Produktifitas Kerja Pegawai Dinas Pekerjaan Umum Kabupaten Grobokan. (online). (http//e-journal:undip.ac.id). diakses 10 Februari 2017.

Sofyandi, Herman. 2008. Manajemen Sumberdaya Manusia. Edisi Pertama. Graha Ilmu. Yogyakarta.

Sugiyono. 2008. Metode Penelitian Bisnis. CV. Alfabeta. Bandung. 2009. Metode Penelitian Bisnis. CV. Alfabeta. Bandung.

Sukanto Rekohadiprodjo dan T. Hani Handoko. 2001. Organisasi Perusahaan. Edisi Kedua. BPFEYogyakarta. Yogyakarta.

Sunyoto, Danang. 2012. Teori Koesioner dan Analisis Data Sumberdaya Manusia. Cetakan Pertama. Center for Academic Publishing Servis. Yogyakarta.

2012. Manajemen Sumberdaya Manusia. Cetakan Pertama. Center For Academic Publishing Service. Yogyakarta.

Sutrisno, Edy. 2009. Manajemen Sumber Daya Manusia. Edisi Pertama. Kencana Prenada Media Group. Jakarta.

Suwatno dan Doni Juni Priansa. 2011. Manajemen Sumberdaya Manusia Dalam Organisasi Publik dan Bisnis. Cetakan Kedua. CV. Alfabeta. Bandung.

Thaif, Ilham. 2015. Effect of Training, Compensation and Work Discipline against Employee Job Performance (Studies in the Office of PT. PLN (Persero) Service Area and Network Malang). (online). (http//e-journal:unisma.ac.id). diakses 18 Februari 2017.

Timbulang, Stela. 2015. Etos Kerja, Disiplin Kerja, Dan Komitmen Organisasi Pengaruhnya Terhadap
Kinerja Karyawan Pada PT Hasjrat Abadi Cabang MANADO. (online). (http//e-journal:unhas.ac.id). diakses 14 Februari 2017.

Umar, Husein. 2008. Metode Penelitian Untuk Skripsi Dan Tesis Bisnis. Jakarta: PT. Raja Grafindo Persada.

Wibisono, Dermawan. 2011. Manajemen Kinerja Korporasi dan Organisasi. Erlangga. Jakarta.

Wibowo. 2012. Manajemen Kinerja. Edisi Ketiga. PT Raja Grafiindo Persada. Jakarta.

Yani, M..2012. Manajemen Sumber Daya Manusia.Jakarta: Mitra Wacana Media.

Yuarto, Simon. 2014. Melakukan penelitian dengan judul "Pengaruh Disiplin Dan Setres Kerja Terhadap Kinerja Perawat. (online). (http//ejournal:unnes.ac.id). diakses 14 Februari 2017. 